\title{
Article \\ Secondary Metabolites with $\alpha$-Glucosidase Inhibitory Activity from Mangrove Endophytic Fungus Talaromyces sp. CY-3
}

\author{
Wencong Yang ${ }^{1}{ }^{(D)}$, Qi Tan ${ }^{1}$, Yihao Yin ${ }^{1}$, Yan Chen ${ }^{1,2}$, Yi Zhang ${ }^{3} \mathbb{D}$, Jianying Wu ${ }^{1}$, Leyao Gao ${ }^{1}$, Bo Wang ${ }^{1, *}$ \\ and Zhigang She ${ }^{1, * \mathbb{D}}$
}

1 School of Chemistry, Sun Yat-Sen University, Guangzhou 510275, China; yangwc6@mail2.sysu.edu.cn (W.Y.); tanq27@mail2.sysu.edu.cn (Q.T.); yinyh6@mail2.sysu.edu.cn (Y.Y.); chenyan27@mail2.sysu.edu.cn (Y.C.); wujy89@mail2.sysu.edu.cn (J.W.); gaoly6@mail2.sysu.edu.cn (L.G.)

2 National R \& D Center for Edible Fungus Processing Technology, Henan University, Kaifeng 475004, China

3 Research Institute for Marine Drugs and Nutrition, College of Food Science and Technology, Guangdong Ocean University, Zhanjiang 524088, China; hubeizhangyi@163.com

* Correspondence: ceswb@mail.sysu.edu.cn (B.W.); cesshzhg@mail.sysu.edu.cn (Z.S.)

\section{check for}

updates

Citation: Yang, W.; Tan, Q.; Yin, Y.; Chen, Y.; Zhang, Y.; Wu, J.; Gao, L.; Wang, B.; She, Z. Secondary Metabolites with $\alpha$-Glucosidase Inhibitory Activity from Mangrove Endophytic Fungus Talaromyces sp. CY-3. Mar. Drugs 2021, 19, 492. https://doi.org/10.3390/md19090492

Academic Editors:

RuAngelie Edrada-Ebel,

Chang-Yun Wang and Bin-Gui Wang

Received: 9 August 2021

Accepted: 27 August 2021

Published: 28 August 2021

Publisher's Note: MDPI stays neutral with regard to jurisdictional claims in published maps and institutional affiliations.

Copyright: (c) 2021 by the authors. Licensee MDPI, Basel, Switzerland. This article is an open access article distributed under the terms and conditions of the Creative Commons Attribution (CC BY) license (https:// creativecommons.org/licenses/by/ $4.0 /)$.

\begin{abstract}
Eight new compounds, including two sambutoxin derivatives (1-2), two highly oxygenated cyclopentenones (7-8), four highly oxygenated cyclohexenones (9-12), together with four known sambutoxin derivatives (3-6), were isolated from semimangrove endophytic fungus Talaromyces sp. CY-3, under the guidance of molecular networking. The structures of new isolates were elucidated by analysis of detailed spectroscopic data, ECD spectra, chemical hydrolysis, ${ }^{13} \mathrm{C}$ NMR calculation, and DP4+ analysis. In bioassays, compounds 1-5 displayed better $\alpha$-glucosidase inhibitory activity than the positive control 1-deoxynojirimycin $\left(\mathrm{IC}_{50}=80.8 \pm 0.3 \mu \mathrm{M}\right)$, and the $\mathrm{IC}_{50}$ value was in the range of $12.6 \pm 0.9$ to $57.3 \pm 1.3 \mu \mathrm{M}$.
\end{abstract}

Keywords: Talaromyces sp.; molecular networking; sambutoxin; polyketides; $\alpha$-glucosidase

\section{Introduction}

According to the WHO forecast, the number of diabetes patients will reach 693 million in 2045. Type II diabetes accounts for $90 \%$, and $\alpha$-glucosidase inhibitors originating from natural products, such as acarbose, miglitol, and voglibose, are used to treat type II diabetes [1]. However, most clinical antidiabetic drugs cause side effects [2]. Therefore, there is an urgent need to find and discover new antidiabetic drugs.

Mangrove endophytic fungi are an important resource to provide a large number of structurally unique secondary metabolites [3,4] with good biological activities, such as $\alpha$-glucosidase inhibitory activities [5], antibacterial [6], antifungal [7], anti-insect [8], antitumor [9], antiviral [10], antioxidant [11], and anti-inflammatory activities [12]. As part of our ongoing search for new compounds with $\alpha$-glucosidase inhibitory activities from mangrove-derived fungi [5,12-14], secondary metabolites of fungus Talaromyces sp. CY-3, collected from the fresh leaves of the semimangrove Hibiscus tiliaceus in Zhanjiang, were studied.

Recently, the advent of visual molecular network technology has led to a new perspective in the research of natural products [15]. Global Natural Product Social (GNPS) can establish a molecular network to classify compounds with the same LC-MS/MS ion fragments into similar clusters. Moreover, it can rapidly discover novel compounds through accurate MS data and database comparison [16].

Extracts of CY-3 were analyzed by LC-MS/MS, and a visible molecular network was generated (Figure 1). Guided by MS/MS-based molecular networking through the GNPS platform, small clusters of compounds were tracked for isolation with $\mathrm{m} / \mathrm{z}$ $492[\mathrm{M}+\mathrm{K}]^{+}, 336[\mathrm{M}+\mathrm{H}]^{+}, 438[\mathrm{M}+\mathrm{H}]^{+}, 474[\mathrm{M}+\mathrm{Na}]^{+}, 201[\mathrm{M}+\mathrm{H}]^{+}$, and $187[\mathrm{M}+\mathrm{H}]^{+}$. Two new sambutoxin derivatives (1-2), six highly oxygenated new polyketides (7-12), and 
four known sambutoxin derivatives (3-6) were isolated (Figure 2). Herein, the isolation, structure elucidation, and $\alpha$-glucosidase inhibitory activity of all compounds are presented.

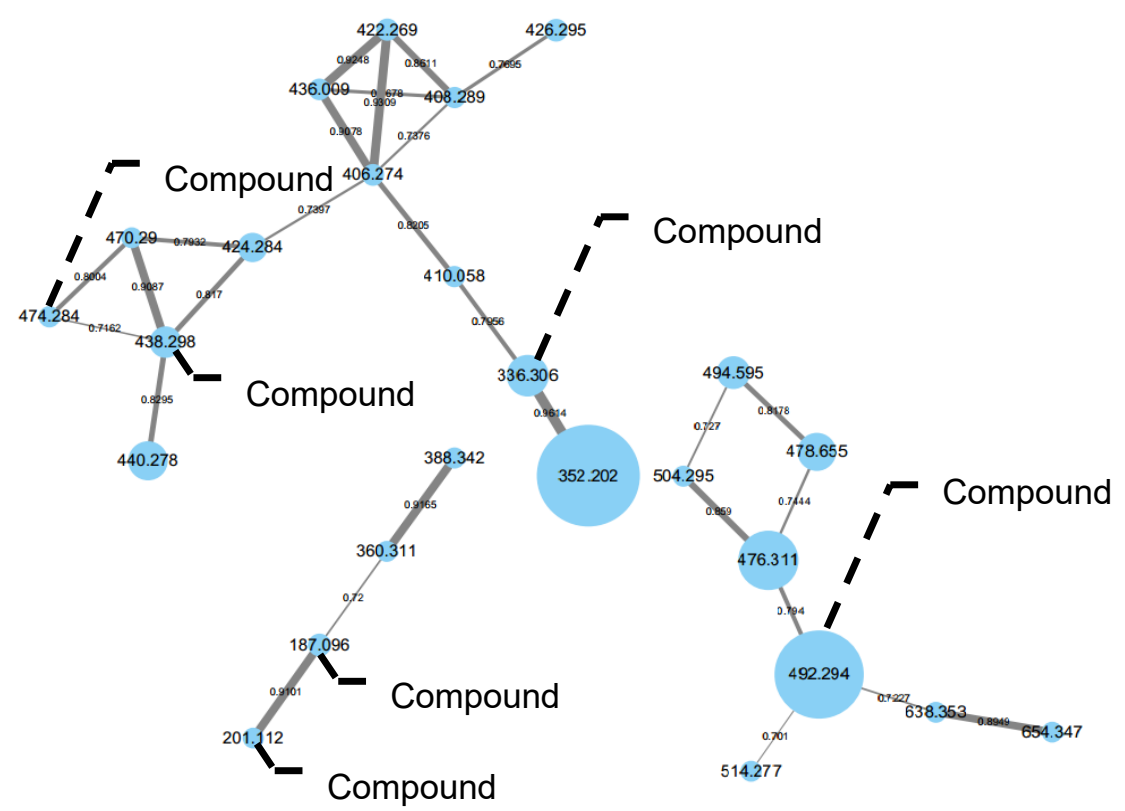

Figure 1. Clusters of nodes from Talaromyces sp. for compounds 1-3, 5, 8, and 10-12.

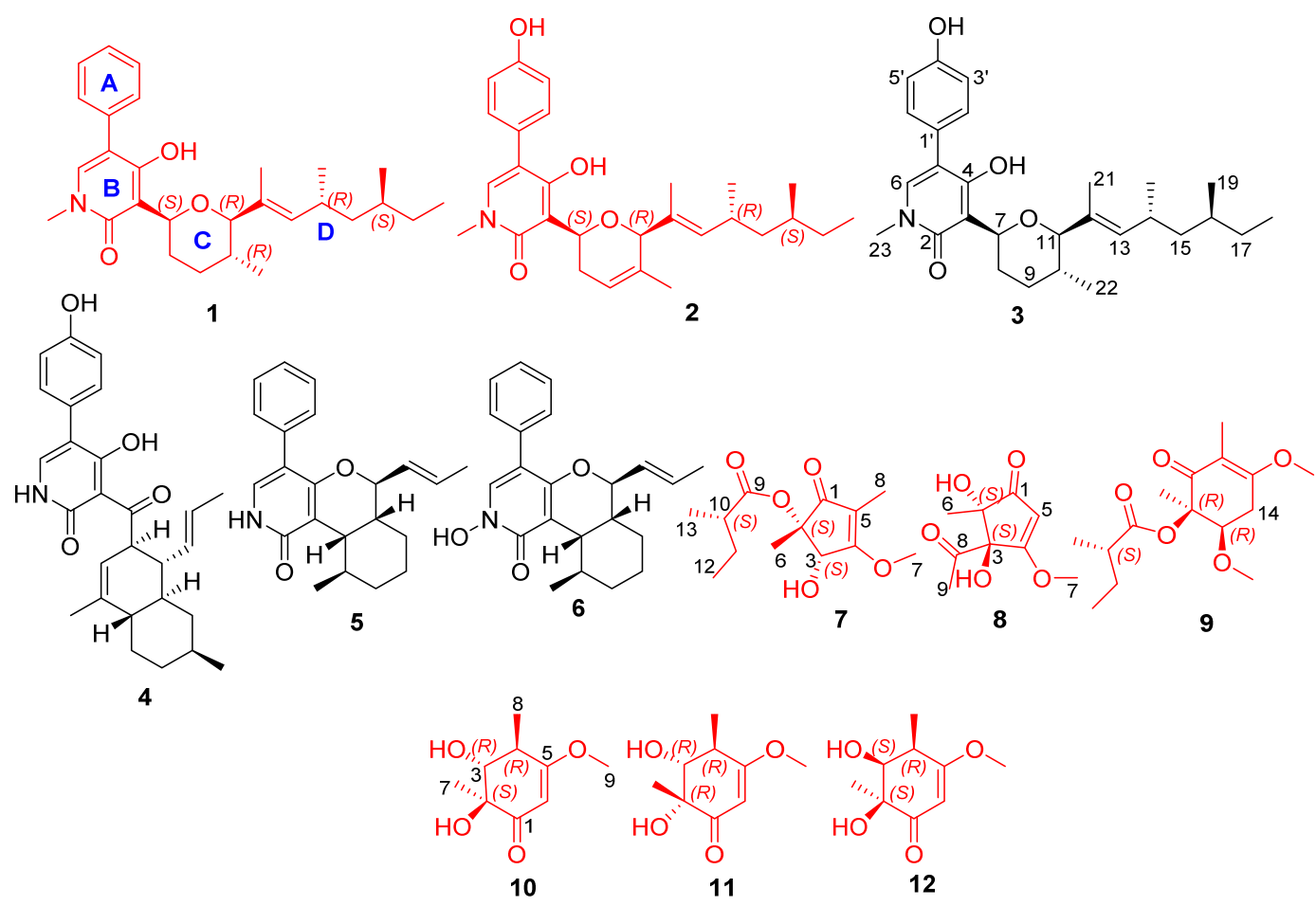

Figure 2. Structure of compounds 1-12.

\section{Results}

\subsection{Structure Identification}

Sambutoxin A (1), obtained as a light-yellow oil, was displayed to have a molecular formula of $\mathrm{C}_{28} \mathrm{H}_{37} \mathrm{NO}_{4}$ with 10 degrees of unsaturation at $m / z 438.2999[\mathrm{M}+\mathrm{H}]^{+}$(calcd. 438.3002), as shown by a positive HR-ESI-MS spectrum. The ${ }^{1} \mathrm{H}$ NMR of 1 showed six methyls $\left(\delta_{\mathrm{H}} 0.74,0.82,0.83,0.90,1.61\right.$, and 3.50$)$, four methylenes $\left(\delta_{\mathrm{H}} 1.03,1.19,1.34,1.44\right.$, $1.64,1.91$, and 2.09), five methines $\left(\delta_{\mathrm{H}} 1.30,1.69,2.45,3.53\right.$, and 5.02), seven unsaturated 
protons $\left(\delta_{\mathrm{H}} 5.18,7.14,7.32,7.39\right.$, and 7.42), and one exchangeable hydrogen atom $\left(\delta_{\mathrm{H}} 9.99\right)$. Its ${ }^{13} \mathrm{C}$ NMR displayed a total of 28 carbons resonances, six methyls $\left(\delta_{\mathrm{C}} 11.3,11.7,17.8,19.7\right.$, 20.8 , and 37.2), four methylenes $\left(\delta_{\mathrm{c}} 29.0,30.8,32.2\right.$, and 44.8$)$, five methines $\left(\delta_{\mathrm{c}} 29.7,32.1\right.$, $32.5,78.0$, and 92.7), seven carbons with unsaturated protons $\left(\delta_{\mathrm{c}} 127.5,128.4,129.3,136.4\right.$, and 138.1), and six quaternary carbons $\left(\delta_{\mathrm{c}} 110.4,115.2,130.4,134.2,161.5\right.$, and 162.0). The HMBC from $\mathrm{H}-13$ to $\mathrm{C}-12$, from $\mathrm{H}-21$ to $\mathrm{C}-13$, together with the ${ }^{1} \mathrm{H}-{ }^{1} \mathrm{H}$ COSY $\mathrm{H}-13 / \mathrm{H}-$ 14(/H-20)/H-15/H-16(/H-19)/H-17/H-18 formed the side chain D. HMBC from H-11 to $\mathrm{C}-7$, together with ${ }^{1} \mathrm{H}-{ }^{1} \mathrm{H}$ COSY $\mathrm{H}-7 / \mathrm{H}-8 / \mathrm{H}-9 / \mathrm{H}-10(/ \mathrm{H}-22) / \mathrm{H}-11$, established the ring $\mathrm{C}$ moiety. HMBC from $\mathrm{H}-6$ to $\mathrm{C}-2, \mathrm{C}-4$, and $\mathrm{C}-5$ and from $\mathrm{H}-23$ to $\mathrm{C}-2$ and $\mathrm{C}-6$, constructed a ring $\mathrm{B}$ moiety. ${ }^{1} \mathrm{H}-{ }^{1} \mathrm{H}$ COSY H-2' $/ \mathrm{H}-3^{\prime} / \mathrm{H}-4^{\prime} / \mathrm{H}-5^{\prime} / \mathrm{H}-6^{\prime}$, together with HMBC from $\mathrm{H}-2^{\prime}$ to $\mathrm{C}-1^{\prime}$ and from $\mathrm{H}-6^{\prime}$ to $\mathrm{C}-\mathrm{1}^{\prime}$, constructed ring $\mathrm{A}$. Finally, rings $\mathrm{A}, \mathrm{B}, \mathrm{C}$, and side chain $\mathrm{D}$ were connected by the HMBCs from $\mathrm{H}-6$ ' to $\mathrm{C}-5, \mathrm{H}-7$ to $\mathrm{C}-2, \mathrm{C}-3$, and $\mathrm{C}-4$, and $\mathrm{H}-21$ to $\mathrm{C}-11$. The 1D and 2D NMR data were similar to those of 3 (Table 1). The only difference between them was that the $4^{\prime}-\mathrm{OH}\left(\delta_{\mathrm{C}} 156.5\right)$ is reduced to a hydrogen atom $\left(\delta_{\mathrm{H}} 7.29-7.34, \delta_{\mathrm{C}} 127.5\right)$. Thus, the planar structure of $\mathbf{1}$ was shown (Figure 3).

Table 1. ${ }^{1} \mathrm{H}$ NMR and ${ }^{13} \mathrm{C}$ NMR of $\mathbf{1}-\mathbf{3}$.

\begin{tabular}{|c|c|c|c|c|c|c|}
\hline \multirow{2}{*}{ NO. } & \multicolumn{2}{|c|}{$1\left(\mathrm{CDCl}_{3}\right)$} & \multicolumn{2}{|c|}{$2\left(\mathrm{CDCl}_{3}\right)$} & \multicolumn{2}{|c|}{$3\left(\mathrm{CDCl}_{3}\right)$} \\
\hline & $\delta_{\mathrm{C}}$, Type & $\delta_{\mathrm{H}}(J$ in $\mathrm{Hz})$ & $\delta_{\mathrm{C}}$, Type & $\delta_{\mathrm{H}}(J$ in $\mathrm{Hz})$ & $\delta_{\mathrm{C}}$, Type & $\delta_{\mathbf{H}}(J$ in $\mathrm{Hz})$ \\
\hline 2 & $161.5, \mathrm{C}$ & & $161.7, \mathrm{C}$ & & $162.7, \mathrm{C}$ & \\
\hline 3 & $110.4, \mathrm{C}$ & & 110.1, C & & $110.4, \mathrm{C}$ & \\
\hline 4 & $162.0, \mathrm{C}$ & & $162.5, \mathrm{C}$ & & $162.4, \mathrm{C}$ & \\
\hline 5 & $115.2, \mathrm{C}$ & & $115.4, \mathrm{C}$ & & $115.9, \mathrm{C}$ & \\
\hline 6 & 136.4, $\mathrm{CH}$ & $7.14, \mathrm{~s}$ & 136.2, $\mathrm{CH}$ & $7.11, \mathrm{~s}$ & 136.0, $\mathrm{CH}$ & $7.12, \mathrm{~s}$ \\
\hline 7 & $78.0, \mathrm{CH}$ & $5.02, \mathrm{~d},(9.1)$ & 73.7, CH & $\begin{array}{c}5.17, \mathrm{dd} \\
(10.5,3.1)\end{array}$ & $77.8, \mathrm{CH}$ & $5.02, \mathrm{~d},(9.0)$ \\
\hline 8 & $30.8, \mathrm{CH}_{2}$ & $\begin{array}{l}1.64-1.69, \mathrm{~m}, \\
2.09, \mathrm{~d},(11.4)\end{array}$ & $29.9, \mathrm{CH}_{2}$ & $\begin{array}{l}1.25-1.31, \mathrm{~m} \\
2.25-2.35, \mathrm{~m}\end{array}$ & $30.9, \mathrm{CH}_{2}$ & $\begin{array}{l}1.64-1.70, \mathrm{~m}, \\
2.09, \mathrm{~d},(11.4)\end{array}$ \\
\hline 9 & $32.3, \mathrm{CH}_{2}$ & $\begin{array}{l}\text { 1.44, d, (10.1) } \\
1.91, \mathrm{~d},(13.1)\end{array}$ & $121.9, \mathrm{CH}$ & $5.72, \mathrm{~d},(5.2)$ & $32.2, \mathrm{CH}_{2}$ & $\begin{array}{l}1.44, d,(10.1) \\
1.91, d,(13.1)\end{array}$ \\
\hline 10 & $32.5, \mathrm{CH}$ & $1.64-1.69, \mathrm{~m}$ & $132.9, \mathrm{C}$ & & $32.1, \mathrm{CH}$ & $1.64-1.70, \mathrm{~m}$ \\
\hline 11 & $92.7, \mathrm{CH}$ & $3.53, \mathrm{~s}$ & $86.9, \mathrm{CH}$ & $4.56, \mathrm{~s}$ & $92.7, \mathrm{CH}$ & $3.53, \mathrm{~s}$ \\
\hline 12 & $130.4, \mathrm{C}$ & & $130.2, \mathrm{C}$ & & $130.3, \mathrm{C}$ & \\
\hline 13 & $138.1, \mathrm{CH}$ & $5.18, \mathrm{~d},(9.5)$ & 139.7, CH & $5.29, \mathrm{~d},(9.6)$ & $138.1, \mathrm{CH}$ & $5.18, \mathrm{~d},(9.5)$ \\
\hline 14 & $29.7, \mathrm{CH}$ & $2.42-2.49, \mathrm{~m}$ & $30.0, \mathrm{CH}$ & $2.40-2.50, \mathrm{~m}$ & $29.7, \mathrm{CH}$ & $2.42-2.49, \mathrm{~m}$ \\
\hline 15 & $44.8, \mathrm{CH}_{2}$ & $\begin{array}{l}1.01-1.07, \mathrm{~m} \\
1.16-1.21, \mathrm{~m}\end{array}$ & $44.8, \mathrm{CH}_{2}$ & $\begin{array}{l}1.01-1.04, \mathrm{~m}, \\
1.25-1.31, \mathrm{~m}\end{array}$ & $44.8, \mathrm{CH}_{2}$ & $\begin{array}{l}1.01-1.07, \mathrm{~m} \\
1.16-1.21, \mathrm{~m}\end{array}$ \\
\hline 16 & $32.1, \mathrm{CH}$ & $1.29-1.35, \mathrm{~m}$ & $32.2, \mathrm{CH}$ & $1.25-1.31, \mathrm{~m}$ & $32.4, \mathrm{CH}$ & $1.29-1.34, \mathrm{~m}$ \\
\hline 17 & 29.0, $\mathrm{CH}_{2}$ & $\begin{array}{l}1.01-1.07, \mathrm{~m} \\
1.29-1.35, \mathrm{~m}\end{array}$ & 29.0, $\mathrm{CH}_{2}$ & $\begin{array}{l}1.01-1.04, \mathrm{~m}, \\
1.25-1.31, \mathrm{~m}\end{array}$ & 29.0, $\mathrm{CH}_{2}$ & $\begin{array}{l}1.01-1.07, \mathrm{~m} \\
1.29-1.34, \mathrm{~m}\end{array}$ \\
\hline 18 & $11.3, \mathrm{CH}_{3}$ & $0.83, \mathrm{~s}$ & $11.0, \mathrm{CH}_{3}$ & $1.53, \mathrm{~d},(1.3)$ & $11.3, \mathrm{CH}_{3}$ & $0.83, \mathrm{~s}$ \\
\hline 19 & $19.7, \mathrm{CH}_{3}$ & $0.82, \mathrm{~d},(6.5)$ & $20.8, \mathrm{CH}_{3}$ & $0.90, \mathrm{~d},(6.6)$ & $19.7, \mathrm{CH}_{3}$ & $0.82, \mathrm{~d},(6.5)$ \\
\hline 20 & $20.8, \mathrm{CH}_{3}$ & $0.90, \mathrm{~d},(6.6)$ & $19.7, \mathrm{CH}_{3}$ & $0.82, \mathrm{~d},(6.4)$ & $20.8, \mathrm{CH}_{3}$ & $0.90, d,(6.6)$ \\
\hline 21 & $11.7, \mathrm{CH}_{3}$ & $1.61, \mathrm{~s}$ & $11.3, \mathrm{CH}_{3}$ & $1.49, \mathrm{~s}$ & $11.7, \mathrm{CH}_{3}$ & $1.61, \mathrm{~s}$ \\
\hline 22 & $17.8, \mathrm{CH}_{3}$ & $0.74, \mathrm{~d},(6.5)$ & $19.1, \mathrm{CH}_{3}$ & $0.81, \mathrm{~s}$ & $17.7, \mathrm{CH}_{3}$ & $0.74, \mathrm{~d},(6.5)$ \\
\hline 23 & $37.2, \mathrm{CH}_{3}$ & $3.50, \mathrm{~s}$ & 37.3, $\mathrm{CH}_{3}$ & $3.50, \mathrm{~s}$ & $37.4, \mathrm{CH}_{3}$ & $3.50, \mathrm{~s}$ \\
\hline $1^{\prime}$ & $134.2, \mathrm{C}$ & & $125.9, \mathrm{C}$ & & $125.2, \mathrm{C}$ & \\
\hline $2^{\prime}$ & $129.3, \mathrm{CH}$ & 7.35-7.44, m & $130.6, \mathrm{CH}$ & $7.26, d,(9.0)$ & $130.5, \mathrm{CH}$ & $7.26, d,(9.0)$ \\
\hline $3^{\prime}$ & $128.4, \mathrm{CH}$ & $7.35-7.44, \mathrm{~m}$ & $115.5, \mathrm{CH}$ & $6.87, \mathrm{~d},(8.1)$ & 115.6, CH & $6.92, d,(8.1)$ \\
\hline $4^{\prime}$ & $127.5, \mathrm{CH}$ & 7.29-7.34, m & $155.8, \mathrm{C}$ & & $156.5, \mathrm{C}$ & \\
\hline $5^{\prime}$ & $128.4, \mathrm{CH}$ & 7.35-7.44, m & $115.5, \mathrm{CH}$ & $6.87, \mathrm{~d},(8.1)$ & 115.6, CH & $6.92, d,(8.1)$ \\
\hline $6^{\prime}$ & 129.3, CH & $7.35-7.44, \mathrm{~m}$ & $130.6, \mathrm{CH}$ & $7.26, d,(9.0)$ & $130.5, \mathrm{CH}$ & $7.26, \mathrm{~d},(9.0)$ \\
\hline $4^{\prime}-\mathrm{OH}$ & & $9.99, \mathrm{~s}$ & & $9.83, \mathrm{~s}$ & & $9.83, \mathrm{~s}$ \\
\hline
\end{tabular}




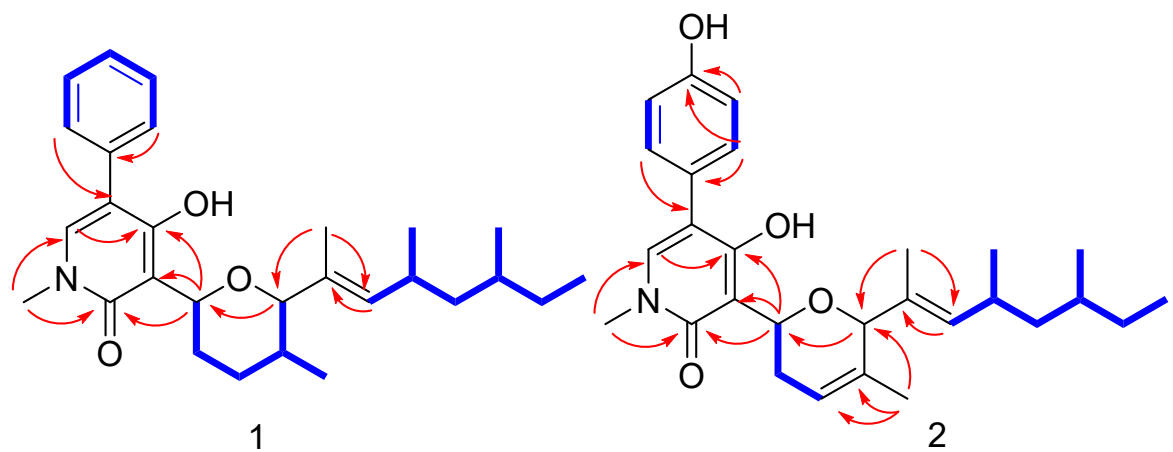

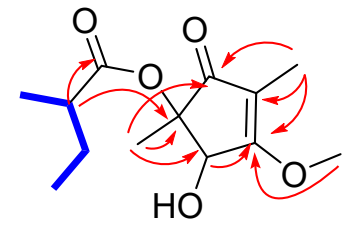

7

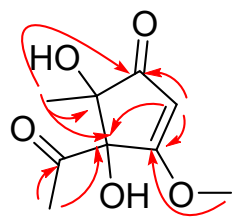

8

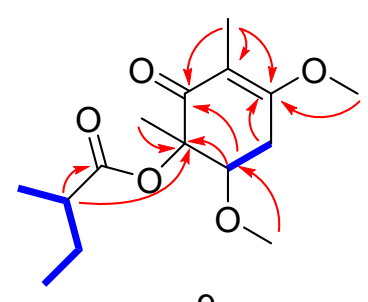

9

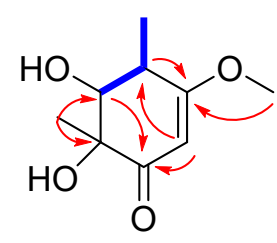

$102 S, 3 R, 4 R$

$112 R, 3 R, 4 R$ $122 S, 3 S, 4 R$

Figure 3. HMBC (red arrow) and key COSY (blue bold line) of 1-2 and 7-12.

The relative configuration of ring $C$ and the double bond between $C-12$ and $C-13$ of compound 1 were defined by the NOESY spectrum. The correlations of $\mathrm{H}-22 / \mathrm{H}-7 / \mathrm{H}-11$ and $\mathrm{H}-14 / \mathrm{H}-21$ were also observed in the NOESY spectrum (Figure 4), which means H-22, $\mathrm{H}-7$, and $\mathrm{H}-11$ were on the same side, as were $\mathrm{H}-14$ and $\mathrm{H}-21$. Therefore, the relative configuration of $\mathrm{C}-7, \mathrm{C}-10$, and $\mathrm{C}-11$ in ring $\mathrm{C}$ was deduced to be $\left(7 \mathrm{~S}^{*}, 10 R^{*}, 11 R^{*}\right)$, and the double bond between $\mathrm{C}-12$ and $\mathrm{C}-13$ was assigned to be $(E)$. In the present work, assigning the configurations at C-14 and C-16 in the aliphatic side chains of $\mathbf{1}$ was a challenging task due to the high conformational flexibility of fatty chains. As described in the literature, the absolute side-chain configurations for C-14 and C-16 were also determined by ${ }^{13} \mathrm{C}$ NMR calculation and DP4+ analysis $[17,18] .(14 R, 16 S)-\mathbf{1}$ was assigned with a $100 \%$ probability (Figures S68 and S69). Consequently, the side-chain configurations of C-14 and C-16 of 1 were assigned to be $14 R, 16 S$. The absolute configuration of 1 was determined by comparing the calculated ECD spectra $(7 S, 10 R, 11 R, 14 R, 16 S)-1$ and $(7 R, 10 S, 11 S, 14 R, 16 S)-\mathbf{1}$ with the experimental one. The calculated ECD curves $(7 S, 10 R, 11 R, 14 R, 16 S)-1$ showed better agreement with the experimental one (Figure $5 \mathrm{~A}$ ). Thus, the absolute configuration of $\mathbf{1}$ was assigned to be $7 S, 10 R, 11 R, 13 E, 14 R, 16 S$. Compounds 1 and $\mathbf{3}$ share a common biosynthetic pathway for sambutoxin derivatives, which is consistent with the configuration reported in the literature $[19,20]$.

Sambutoxin B (2), also isolated as a light-yellow oil, displayed a molecular formula of $\mathrm{C}_{28} \mathrm{H}_{37} \mathrm{NO}_{4}$ with 11 degrees of unsaturation at $m / z$ 452.2794 [M+H] $]^{+}$(calcd. 452.2795) by positive HR-ESI-MS spectrum. Its 1D and 2D NMR were similar to 3 . The only difference between them was that the single bond between $\mathrm{C}-9\left(\delta_{\mathrm{H}} 1.44,1.97, \delta_{\mathrm{C}} 32.2\right)$ and C-10 $\left(\delta_{\mathrm{H}} 1.64-1.70, \delta_{\mathrm{C}} 32.1\right)$ was converted to a double bond $\left(\delta_{\mathrm{H}} 5.72, \delta_{\mathrm{C}} 121.9,132.9\right)$. Thus, the planar structure of 2 was as shown in Figure 3. The correlations of $\mathrm{H}-7 / \mathrm{H}-11$ and $\mathrm{H}-14 / \mathrm{H}-21$ were observed in the NOESY spectrum (Figure 4). Thus, the double bond between $C-12$ and $C-13$ was assigned to be $(E)$, and the relative configuration was deduced to be $\left(7 S^{*}, 11 R^{*}\right)$. The calculated ECD spectra of $(7 S, 11 R)-2$ and $(7 R, 11 S)-2$ were compared to the measured one, and the calculated ECD curve of $(7 S, 11 R)-2$ was showed a good agreement with the experimental one (Figure 5B). The stereochemistry of C-14 and C-16 was biogenetically established as $14 R, 16 S$. Moreover, they were also verified by ${ }^{13} \mathrm{C} N M R$ calculation and DP4+ probability (Figures S70 and S71). Thus, the absolute configuration of 2 was determined as $7 S, 11 R, 13 E, 14 R, 16 S$. 


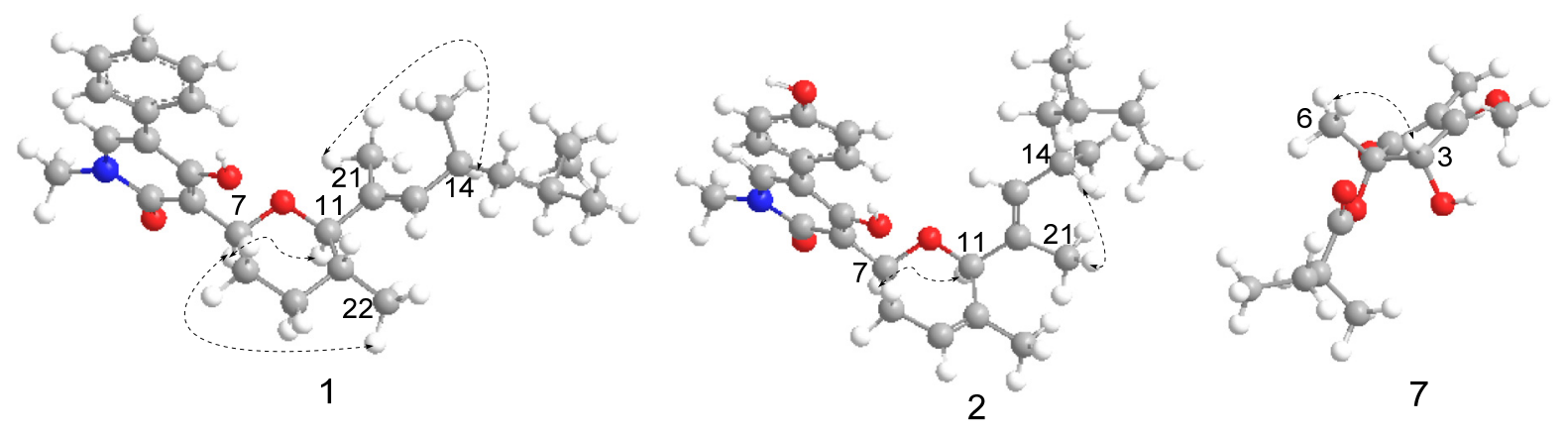

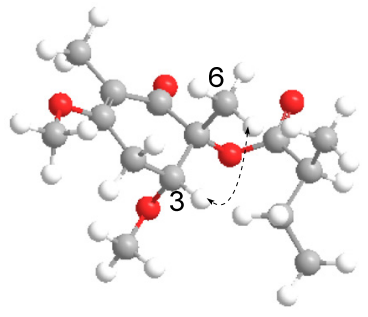

9

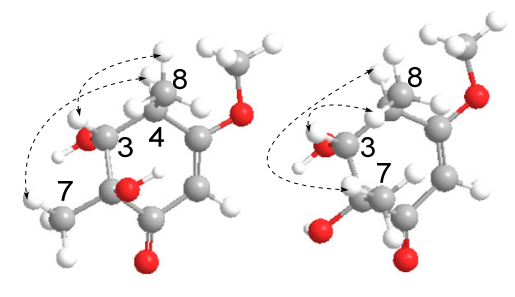

10
11

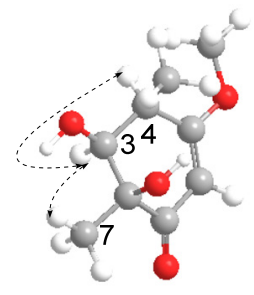

12

Figure 4. NOESY correlations of 1-2 and 7-12.

Talaketides $\mathrm{A}(7)$ was isolated as a yellow oil, and its molecular formula was determined as $\mathrm{C}_{13} \mathrm{H}_{20} \mathrm{O}_{5}$ by the HR-ESI-MS data at $\mathrm{m} / z 279.1197[\mathrm{M}+\mathrm{Na}]^{+}$(calcd. 279.1203). The ${ }^{1} \mathrm{H}$ NMR of 7 displayed four methyls, one methylene, two methines, and one methoxy (Table 2). Its ${ }^{13} \mathrm{C}$ NMR showed a total of 13 carbons resonances, including four methyls, one methylene, two methines, one methoxy, one ester carboxyl, one carbonyl, two olefinic carbons, and one quaternary carbon (Table 3). The HMBC from $\mathrm{H}-3$ to $\mathrm{C}-4, \mathrm{H}-6$ to $\mathrm{C}-1, \mathrm{C}-2$, and C-3, H-7 to C-4, H-8 to C-1, C-4, and C-5, H-10 to $\mathrm{C}-2$ and C-9, together with the ${ }^{1} \mathrm{H}^{-1} \mathrm{H}$ COSY correlation from $\mathrm{H}-13 / \mathrm{H}-10 / \mathrm{H}-11 / \mathrm{H}-12$, formed the planar structure. In order to determine the absolute ring configuration of 7 , the ECD of $(2 S, 3 S)-7,(2 R, 3 R)-7,(2 S, 3 R)-7$, and $(2 R, 3 S)-7$ was compared with the measured one. $(2 S, 3 S)-7$ showed a good agreement with the experimental one (Figure 5C). Furthermore, the side chain of 7 was hydrolysis in $1 \mathrm{M} \mathrm{NaOH}$ solution and compared to the standard of (S)-2-methylbutanoic acid and (R)-2-methylbutanoic acid through a chiral column by HPLC (Figure 6 and Figure S72). The retention time of hydrolyzate matched with (S)-2-methylbutanoic acid. Thus, the absolute configuration of 7 was determined as $2 S, 3 S, 10 S$.

Talaketides $\mathrm{C}(9)$ was isolated as a yellow oil, and its molecular formula was determined as $\mathrm{C}_{15} \mathrm{H}_{24} \mathrm{O}_{5}$ by the HR-ESI-MS data at $\mathrm{m} / z 307.1517$ [M+Na] ${ }^{+}$(calcd. 307.1516). The 1D and 2D NMR were also similar to 7, and the only difference between them was compound 9 had one more methoxy group $\left(\delta_{\mathrm{H}} 3.16, \delta_{\mathrm{c}} 51.8\right)$ and one more methylene group $\left(\delta_{\mathrm{H}} 2.82,3.03, \delta_{\mathrm{c}} 31.2\right)$ than compound 7. According to the HMBCs, the methylene group was connected oxymethine $\left(\delta_{\mathrm{H}} 5.10, \delta_{\mathrm{c}} 71.7\right)$ and a quaternary carbon $\left(\delta_{\mathrm{c}} 188.2\right)$, and methoxy was connected to oxymethine $\left(\delta_{\mathrm{H}} 5.10, \delta_{\mathrm{c}} 71.7\right)$, thus the planar structure of 9 was established (Figure 3). The NOESY correlation of H-5 to H-12 was observed (Figure 4$)$, and the ECD curves of $(2 R, 3 R)$ and $(2 S, 3 S)$ were compared to the measured one. The calculated ECD of $(2 R, 3 R)$ showed a good agreement with the experimental one (Figure 5E), and the side-chain stereostructure of C-10 was also determined as $10 \mathrm{~S}$ through chemical hydrolysis. (Figure 6 and Figure S72). Therefore, the absolute configuration of 9 was determined as $2 R, 3 R, 10 S$.

Talaketides D (10) was isolated as a light-yellow oil, and its molecular formula was determined as $\mathrm{C}_{9} \mathrm{H}_{14} \mathrm{O}_{4}$ by the HR-ESI-MS data at $m / z 209.0783$ [M+Na] ${ }^{+}$(calcd. 209.0784). Analysis of the 1D and 2D NMR spectrum found compound 10 to be similar to the known compound phomaligol D [21]. The only difference between them was the departure of hydroxyl at C-4 $\left(\delta_{\mathrm{c}} 73.1\right.$ changed to $\left.\delta_{\mathrm{H}} 2.55, \delta_{\mathrm{c}} 41.5\right)$. Thus, the planar structure of 10 was 
determined (Figure 3), which was dehydroxylated phomaligol D. H-3/H-8 and H-4/H-7 correlations were observed in the NOESY spectrum, which indicated that the relative configuration of $\mathbf{1 0}$ was $\left(2 S^{*}, 3 R^{*}, 4 R^{*}\right)$ (Figure 4$)$. In order to determine its absolution configuration, the ECD spectra of $(2 S, 3 R, 4 R)-\mathbf{1 0}$ and $(2 R, 3 S, 4 S)-\mathbf{1 0}$ were compared with the measured one. The calculated CD curve of $(2 S, 3 R, 4 R)$ showed a good agreement with the experimental one (Figure 5F). Therefore, the absolution configuration of $\mathbf{1 0}$ was deduced to be $(2 S, 3 R, 4 R)$ and named Talaketides $\mathrm{D}$.
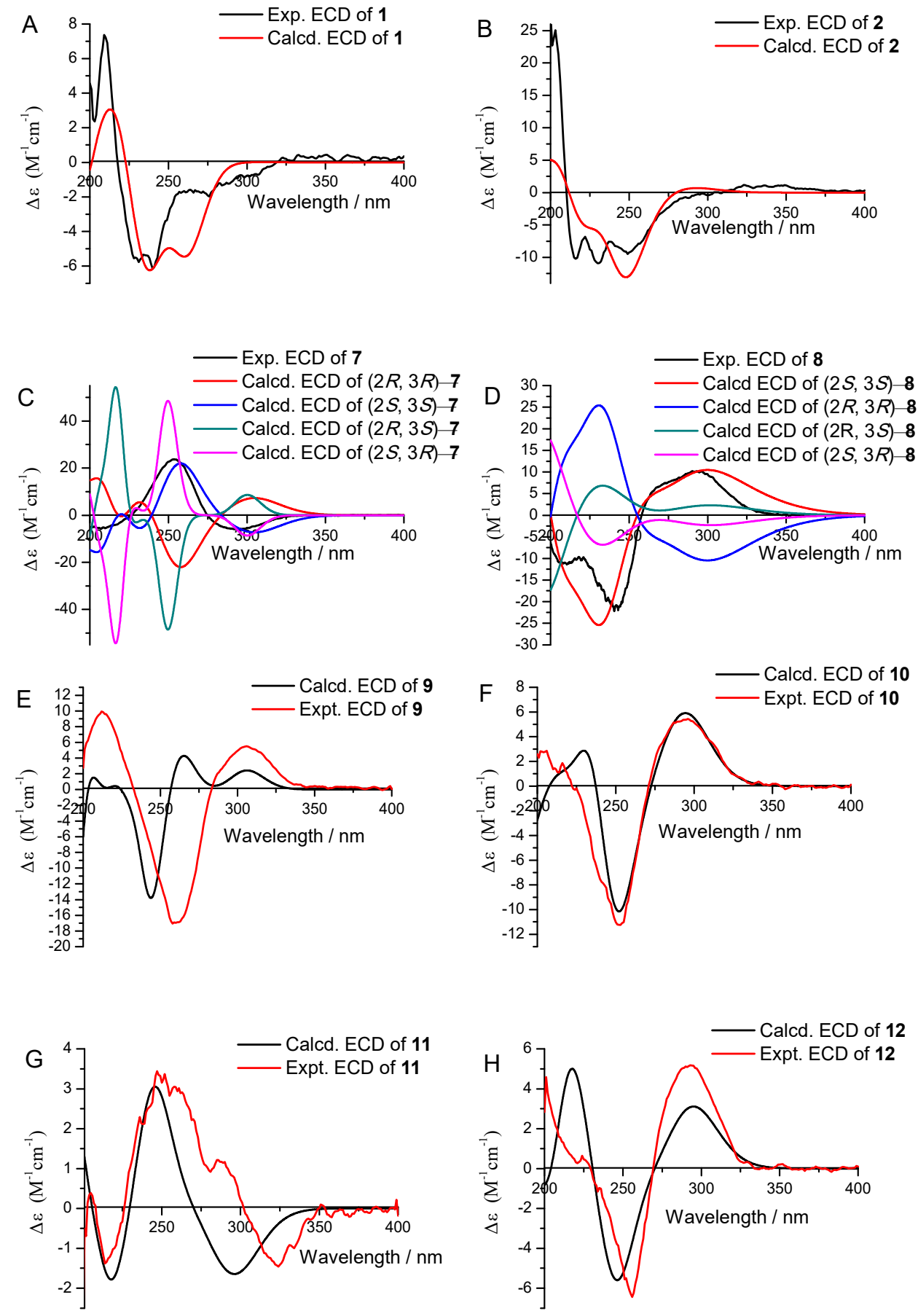

Figure 5. ECD spectra of compounds 1 (A), 2 (B), 7 (C), 8 (D), 9 (E), 10 (F), 11 (G) and 12 (H) in $\mathrm{CH}_{3} \mathrm{OH}$. 
Table 2. ${ }^{1} \mathrm{H}$ NMR of $\mathbf{7 - 1 2 .}$

\begin{tabular}{|c|c|c|c|c|c|c|}
\hline Position & 7 & 8 & 9 & 10 & 11 & 12 \\
\hline 3 & $4.98, \mathrm{~s}$ & & $5.10, \mathrm{q},(6.3)$ & $3.51, \mathrm{~d},(9.5)$ & $3.40, \mathrm{~d},(7.2)$ & $3.80, \mathrm{~d},(3.2)$ \\
\hline 4 & & & & $\begin{array}{c}2.55, \mathrm{dqd} \\
(11.3,6.8 \\
1.7)\end{array}$ & $2.77-2.83, \mathrm{~m}$ & $\begin{array}{c}3.02, \text { qdd, } \\
(7.1,3.2,1.9)\end{array}$ \\
\hline 5 & & $5.55, \mathrm{~s}$ & & & & \\
\hline 6 & $1.30, \mathrm{~s}$ & $1.42, \mathrm{~s}$ & $1.29, \mathrm{~d},(6.4)$ & $5.30, \mathrm{~d},(1.7)$ & $5.33, \mathrm{~d},(1.2)$ & $5.34, \mathrm{~d},(1.9)$ \\
\hline 7 & $4.16, \mathrm{~s}$ & $3.98, \mathrm{~s}$ & $4.10, \mathrm{~s}$ & $1.28, \mathrm{~d},(6.8)$ & $1.30, \mathrm{~d},(7.2)$ & $1.27, \mathrm{~d},(7.1)$ \\
\hline 8 & $1.67, \mathrm{~s}$ & & $1.56, \mathrm{t},(1.8)$ & $1.22, \mathrm{~s}$ & $1.34, \mathrm{~s}$ & $1.30, \mathrm{~s}$ \\
\hline 9 & & $2.20, \mathrm{~s}$ & & $3.75, \mathrm{~s}$ & $3.76, \mathrm{~s}$ & $3.75, \mathrm{~s}$ \\
\hline 10 & $2.37, \mathrm{q},(7.0)$ & & $2.19-2.28, \mathrm{~m}$ & & & \\
\hline & $1.44-1.50, \mathrm{~m}$ & & $1.34-1.40, \mathrm{~m}$ & & & \\
\hline 11 & $1.58-1.65, \mathrm{~m}$ & & $1.44-1.50, \mathrm{~m}$ & & & \\
\hline 12 & $0.94, \mathrm{t},(7.5)$ & & $0.80, \mathrm{t},(7.5)$ & & & \\
\hline 13 & $1.12, \mathrm{~d},(7.0)$ & & $1.02, \mathrm{~d},(7.0)$ & & & \\
\hline 14 & & & $\begin{array}{c}2.82, \mathrm{dq} \\
(18.2,1.8) \\
3.03, \mathrm{dq} \\
(18.2,1.8)\end{array}$ & & & \\
\hline 15 & & & $3.16, \mathrm{~s}$ & & & \\
\hline
\end{tabular}

Table 3. ${ }^{13} \mathrm{C}$ NMR of $7-12$.

\begin{tabular}{ccccccc}
\hline Position & $\mathbf{7}$ & $\mathbf{8}$ & $\mathbf{9}$ & $\mathbf{1 0}$ & $\mathbf{1 1}$ & $\mathbf{1 2}$ \\
\hline 1 & 202.0 & 200.6 & 205.0 & 203.0 & 200.9 & 203.3 \\
2 & 86.4 & 80.4 & 84.3 & 78.4 & 75.5 & 77.7 \\
3 & 73.5 & 92.5 & 71.7 & 78.1 & 78.7 & 79.0 \\
4 & 179.7 & 192.4 & 188.2 & 41.5 & 40.1 & 39.0 \\
5 & 115.6 & 103.3 & 117.5 & 180.1 & 180.5 & 178.9 \\
6 & 19.5 & 23.5 & 14.9 & 99.5 & 99.6 & 99.0 \\
7 & 59.1 & 60.1 & 58.2 & 14.0 & 14.2 & 13.4 \\
8 & 6.08 & 207.2 & 5.6 & 19.2 & 21.4 & 23.6 \\
9 & 177.5 & 27.5 & 176.4 & 57.2 & 57.0 & 57.1 \\
10 & 42.0 & & 42.4 & & & \\
11 & 27.8 & & 27.8 & & & \\
12 & 11.8 & & 11.7 & & & \\
13 & 16.8 & & 16.6 & & & \\
14 & & & 31.2 & & & \\
15 & & & 51.8 & & & \\
\hline
\end{tabular}
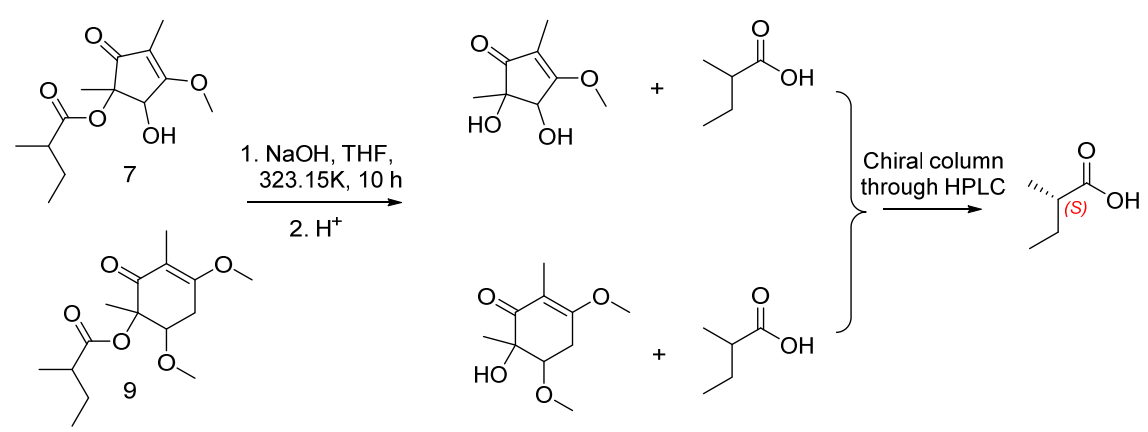

Figure 6. Confirmation for C-10 of compounds 7 and 9 through chemical hydrolysis.

Talaketides E (11) and Talaketides F (12), were also isolated as a light-yellow oil. Similarities in 1D and 2D NMR and HR-ESI-MS indicated that they shared the same planar structure (Figure 3), but the observed correlations were different: one was H-3/H-7/H-8, and the other was H-3/H-4/H-7 in the NOESY spectrum (Figure 4). This phenomenon indicated that their relative configuration was assigned to be $\left(2 R^{*}, 3 R^{*}, 4 R^{*}\right)$ and $\left(2 S^{*}, 3 S^{*}\right.$, 
$\left.4 R^{*}\right)$, respectively. Their stereostructures were also determined by ECD calculation and comparison, and the absolution configuration of $\mathbf{1 1}$ and $\mathbf{1 2}$ was confirmed as $(2 R, 3 R, 4 R)$ and $(2 S, 3 S, 4 R)$, respectively (Figure $5 G$ ).

The structures of compounds 3-6 were identified as (-)-sambutoxin (3) [19], ilicicolin H (4) [22], deoxyleporin B (5) [23], and leporine B (6) [24], respectively, by comparison of their NMR data, MS, CD, and optical rotation with those in the literature.

\subsection{Proposed Biosynthesis Pathway}

A hypothetical biosynthetic pathway for compounds 1-2 and 7-12 was proposed (Figure 7) [25,26]. Compounds 1-2 are the PKS-NRPS biosynthetic pathway. Starting from one L-Phe molecule, one acetyl-CoA molecule, six malonyl-CoA molecules, and four SAM molecules through the PKS pathway formed intermediate $i$. Then, the formation of $\mathbf{1}$ was constructed by rearranging and reducing. The formation of $\mathbf{2}$ was similar to $\mathbf{1}$, and the only difference between them was that L-Phe was replaced by L-Tyr (Figure 7A).

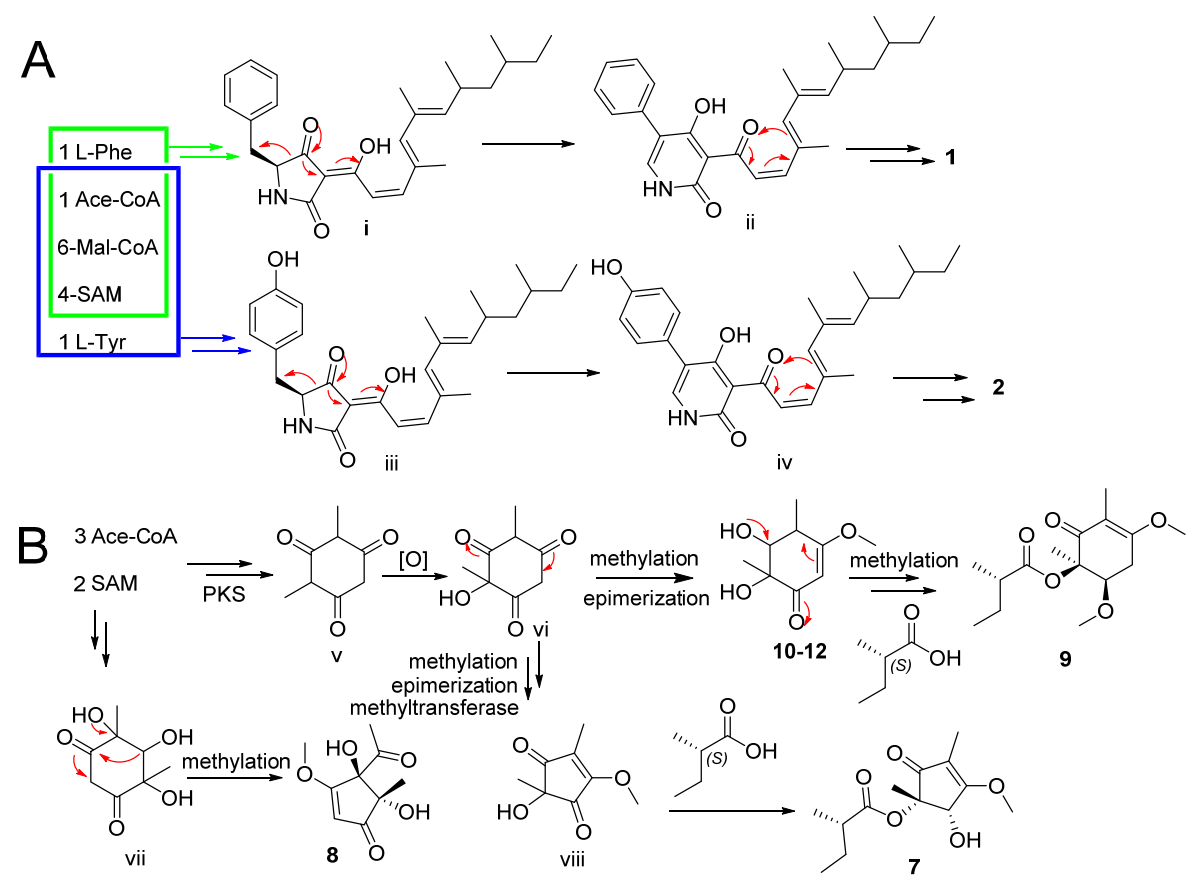

Figure 7. Proposed biogenetic pathways of 1-2 (A) and 7-12 (B).

The remaining compounds 7-12 are considered to be the origin of biosynthetic polyketides. The key intermediate vi was obtained through the PKS pathway, oxidation, and formed 10-12 by electron transfer, methylation, and epimerization. Further electron transfer, methylation, and esterification to form 9. 7 was formed through electron transfer, methylation, epimerization, methyltransferase, and esterification. Together, compound 8 started from two SAM molecules and three acetyl-CoA molecules through the PKS pathway and further rearranging and methylating (Figure 7B).

\section{3. $\alpha$-Glucosidase Inhibitory Activity}

Compounds 1-12 were tested for their $\alpha$-glucosidase inhibitory activity (Table 4). Compounds 1-5 displayed better $\alpha$-glucosidase inhibitory activity with an $\mathrm{IC}_{50}$ value in the range of $12.6 \pm 0.9$ to $57.3 \pm 1.3 \mu \mathrm{M}$ compared to the positive control 1-deoxynojirimycin $\left(\mathrm{IC}_{50}=80.8 \pm 0.3 \mu \mathrm{M}\right)$.

The $\mathrm{IC}_{50}$ value of compound 2 is $37.4 \pm 1.4 \mu \mathrm{M}$, lower than that of compound 1 $(12.6 \pm 0.9 \mu \mathrm{M})$ and compound $3(16.9 \pm 0.6 \mu \mathrm{M})$, which illustrates that the double bond formed between C-9 and C-10 reduced the $\alpha$-glucosidase inhibitory activity. Different from compounds $\mathbf{1}-\mathbf{3}$, compound 5 presented a much bigger $\mathrm{IC}_{50}$ value of $57.3 \pm 1.3 \mu \mathrm{M}$, and 
the $\mathrm{IC}_{50}$ of compound 6 was even bigger than $100 \mu \mathrm{M}$. Therefore, it can be considered that the branch chain attached to ring $C$ contributes a lot to the inhibitory activity. Compound 4 showed relatively higher inhibitory activity ( $\mathrm{IC}_{50}=16.5 \pm 0.7 \mu \mathrm{M}$ ), which may be due to its different structure from the other five.

Table 4. $\alpha$-glucosidase inhibitory activity for 1-12.

\begin{tabular}{cccc}
\hline Compounds & $\mathrm{IC}_{\mathbf{5 0}} / \boldsymbol{\mu M}$ & Compounds & IC $_{\mathbf{5 0}} / \boldsymbol{\mu M}$ \\
\hline $\mathbf{1}$ & $12.6 \pm 0.9$ & $\mathbf{7}$ & $>100$ \\
$\mathbf{2}$ & $37.4 \pm 1.4$ & $\mathbf{8}$ & $>100$ \\
$\mathbf{3}$ & $16.9 \pm 0.6$ & $\mathbf{9}$ & $>100$ \\
$\mathbf{4}$ & $16.5 \pm 0.7$ & $\mathbf{1 0}$ & $>100$ \\
$\mathbf{5}$ & $57.3 \pm 1.3$ & $\mathbf{1 1}$ & $>100$ \\
$\mathbf{6}$ & $>100$ & $\mathbf{1 2}$ & $>100$ \\
1-deoxynojirimycin & $80.8 \pm 0.3$ & & \\
\hline
\end{tabular}

\subsection{Molecular Docking Study}

To explain the difference in inhibitory activity of compounds 1-5 to $\alpha$-glucosidase, molecular docking between them and $\alpha$-glucosidase was carried out using Autodock. The interaction energies of compounds 1-5 with $\alpha$-glucosidase were 8.25, 7.99, 8.85, 9.19, and $7.96 \mathrm{kcal} / \mathrm{mol}$, respectively, which is consistent with the change in $\mathrm{IC}_{50}$ value. Compound 1 mainly formed a hydrogen bond with Glu- 411 with a bond length of $2.85 \AA$ (Figure $8 \mathrm{~A}$ ), 2 formed a hydrogen bond with Ser-241 with a bond length of $3.06 \AA$ (Figure 8B), and 3 formed two hydrogen bonds with Asp-215 and Glu-411 with bond lengths of 3.06 and $2.85 \AA$, respectively. Moreover, compound 4 also formed two hydrogen bonds with Asp242 and Thr-310 with bond lengths of 3.31 and $2.88 \AA$, respectively, while 5 only formed a hydrogen bond with Lys-156 with a bond length of $2.77 \AA$ A. In general, 1, 3, and 4 possess higher interaction energy and stronger interaction with amino acid residue than $\mathbf{2}$ and 5, which explains their significant activity.
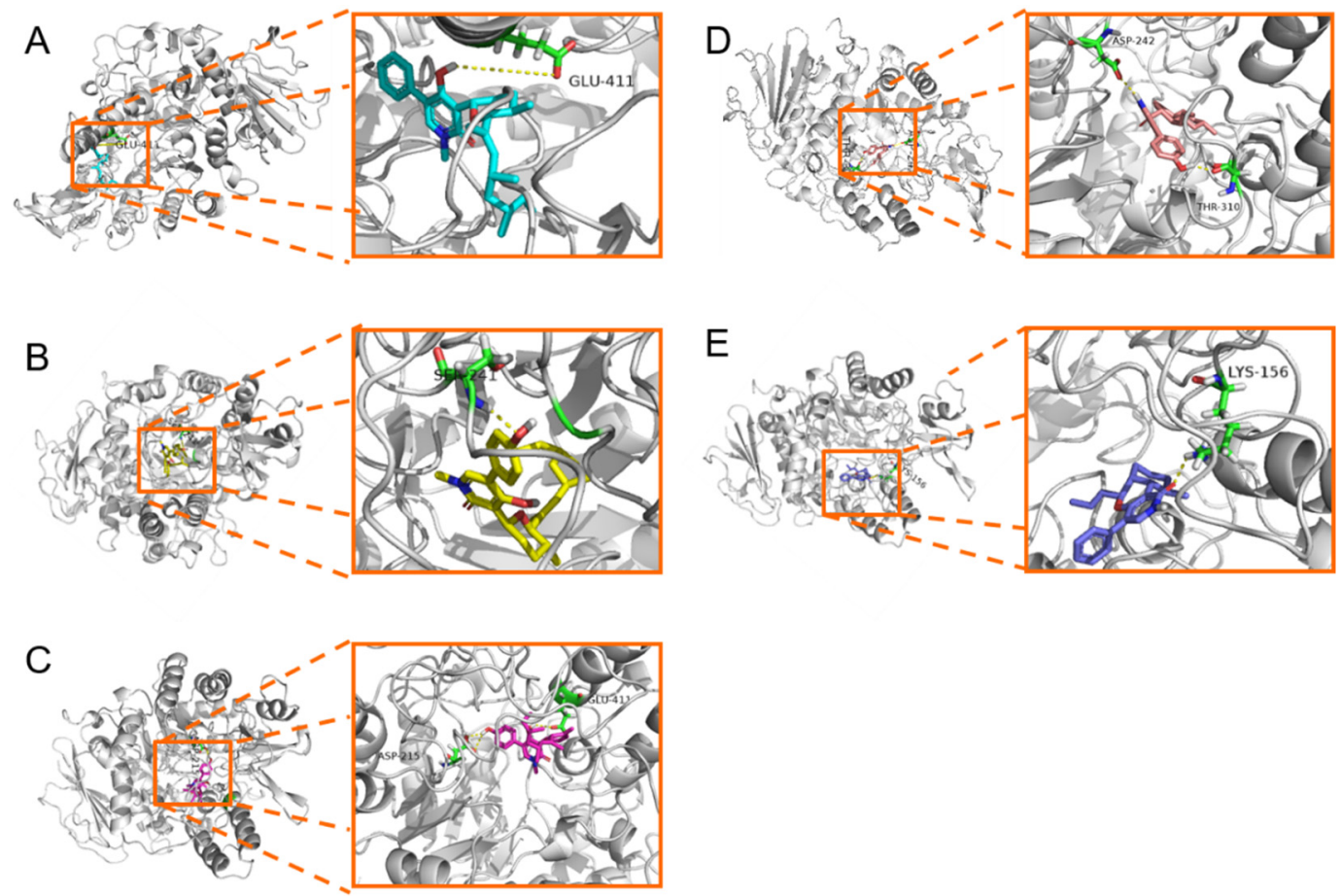

Figure 8. Binding mode of sambutoxins 1 (A), 2 (B), 3 (C), 4 (D), and 5 (E) with $\alpha$-glucosidase. 


\section{Experimental Section}

\subsection{General Experimental Procedures}

The 1D and 2D NMR were recorded on a Bruker Avance $400 \mathrm{MHz}$ spectrometer (Karlsruhe, Germany) at room temperature. HR-ESI-MS spectra of all test compounds were acquired on a ThermoFisher LTQ-Orbitrap-LC-MS spectrometer (Palo Alto, CA, USA). UV-vis spectra were measured on a Shimadzu UV-2600 spectrophotometer (Kyoto, Japan). Optical rotations were acquired on an Anton-Paar MCP500 automatic polarimeter at $25^{\circ} \mathrm{C}$ (Graz, Austria). CD curves were recorded on an Applied Photophysics Chirascan spectropolarimeter (Surrey, UK). All spectrophotometric measurements used a 96-well Bio-Rad microplate reader (Hercules, CA, USA). Solvent was removed by a Heidolph rotavapor with a vacuum pump. Semipreparative HPLC chromatography was used on a U3000 separation module coupled with a DAD detector manufactured by ThermoFisher and a chiral semipreparative column (Nu-Analytical Solutions Co., LTD-packed chiral INB, $5 \mu \mathrm{m}, 4.6 \times 250 \mathrm{~mm}$ ) was used for separation. Column chromatography (CC) used silica gel (200-300 mesh (Qingdao Marine Chemical Factory)) and Sephadex LH-20 (Amersham Pharmacia, Stockholm, Sweden). Precoated silica gel plates (Qingdao Huang Hai Chemical Group Co., G60, F-254) were used for TLC analysis. LC-MS analysis was performed on a Q-TOF manufactured by Waters and a Waters Acquity UPLC BEH C18 column (1.7 $\mu \mathrm{m}$, $2.1 \times 100 \mathrm{~mm}$ ) was used for analysis.

\subsection{Fungal Material}

Fungus CY-3 was isolated from the fresh leaves of the semimangrove Hibiscus tiliaceus (collected in June 2020 from Zhanjiang Mangrove National Nature Reserve in Guangdong Province, China). It was identified as Talaromyces sp. using ITS gene sequencing. The ITS rDNA gene sequence data of the fungi were deposited to GenBank (Accession No. MZ614621), and fungus CY-3 was deposited at Sun Yat-Sen University, China.

\subsection{Fermentation}

CY-3 was activated on a potato dextrose agar (PDA) Petri dish at $28^{\circ} \mathrm{C}$, then cultured in potato dextrose broth (PDB) in $6 \times 500 \mathrm{~mL}$ Erlenmeyer flasks at $28^{\circ} \mathrm{C}$ for 3 days in a shaker to obtain spore inoculum. The routine-scale fermentation was performed in $60 \times 1 \mathrm{~L}$ Erlenmeyer flasks, each containing $50 \mathrm{~mL}$ of $2 \%$ saline and $50 \mathrm{~g}$ of rice. The Erlenmeyer flask containing the culture medium was autoclaved at $121^{\circ} \mathrm{C}$ for $25 \mathrm{~min}$. After cooling to room temperature, $10 \mathrm{~mL}$ of $\mathrm{CY}-3$ inoculum was inoculated in each bottle and incubated at room temperature for 30 days.

\subsection{Extraction and Purification}

After fermentation, the mycelium and medium were extracted three times with EA $(3 \times 20 \mathrm{~L})$. Then, the extracts were condensed under $50{ }^{\circ} \mathrm{C}$ in vacuo and combined to obtain a crude extract $(31 \mathrm{~g})$. The residue was separated by a silica gel column, eluting with a gradient of PE/EA (1:0-0:1) to afford 9 fractions (Frs. 1-8). Fr. 3 (2.4 g) was subjected to Sephadex LH-20 (methanol) to yield five sub-fractions (SFrs. 3.1-3.5). SFrs. 3-1 (352 mg) was applied to silica gel CC (DCM/MeOH $v / v, 200: 1)$ to give compounds 1 (5.3 mg), 2 (4.9 mg), and $3(27.1 \mathrm{mg})$. Compounds $10\left(6.3 \mathrm{mg}, \mathrm{t}_{\mathrm{R}}=7.3 \mathrm{~min}\right), \mathbf{1 1}\left(5.7 \mathrm{mg}, \mathrm{t}_{\mathrm{R}}=9.1 \mathrm{~min}\right)$, and $12\left(4.5 \mathrm{mg}, \mathrm{t}_{\mathrm{R}}=14.3 \mathrm{~min}\right)$ were obtained from SFr3-4 $(298 \mathrm{mg})$ using chiral ND (the gradient was hexane $/ 2$-propanol $v / v, 19: 1$, flow rate: $1 \mathrm{~mL} / \mathrm{min})$. Fr. 4 (2.5 g) was subjected to Sephadex LH-20 (ethanol) to yield three sub-fractions (SFrs. 4.1-4.3). Compounds 4 (8.7 mg), $\mathbf{5}(3.1 \mathrm{mg})$, and $\mathbf{6}(2.9 \mathrm{mg})$ were obtained from SFr4-1 (792 $\mathrm{mg})$ using silica gel CC (DCM/MeOH v/v, 200:1). Fr. 6 (4.7 g) was subjected to Sephadex LH-20 (methanol) to yield three subfractions (SFrs. 6.1-6.3). Compounds 7 (50.1 mg), 8 (6.2 mg), and 9 (4.6 mg) were obtained from SFr6-3 (503 mg) using silica gel CC. (DCM/MeOH v/v, 50:1).

Sambutoxin A (1): $\mathrm{C}_{28} \mathrm{H}_{39} \mathrm{NO}_{3}$; yellow oil; $[\alpha]_{\mathrm{D}}^{25}-30.75^{\circ}($ c $0.74 \mathrm{MeOH}) ; \mathrm{UV}(\mathrm{MeOH})$ $\lambda_{\max }(\log \varepsilon) 240(1.95) \mathrm{nm} ; \mathrm{ECD}(\mathrm{MeOH}) \lambda_{\max }(\Delta \varepsilon) 210(+2.65), 230(-2.04), 243(-2.03)$, 
$279(-0.59) \mathrm{nm} ;{ }^{1} \mathrm{H}\left(400 \mathrm{MHz}, \mathrm{CDCl}_{3}\right)$ and ${ }^{13} \mathrm{C} \mathrm{NMR}\left(100 \mathrm{MHz}, \mathrm{CDCl}_{3}\right)$ data, see Table 1; HR-ESI-MS: $m / z 438.2999[\mathrm{M}+\mathrm{H}]^{+}$(calcd. for $\mathrm{C}_{28} \mathrm{H}_{40} \mathrm{NO}_{3}, 438.3002$ ).

Sambutoxin B (2): $\mathrm{C}_{28} \mathrm{H}_{37} \mathrm{NO}_{4}$; yellow oil; $[\alpha]_{\mathrm{D}}^{25}-10.54^{\circ}$ (c 1.05, MeOH); UV (MeOH) $\lambda_{\max }(\log \varepsilon) 238(2.86) \mathrm{nm}$; ECD $(\mathrm{MeOH}) \lambda_{\max }(\Delta \varepsilon) 217$ (-3.45), 230 (-3.74), 259 (-3.16) $\mathrm{nm} ;{ }^{1} \mathrm{H}\left(400 \mathrm{MHz}, \mathrm{CDCl}_{3}\right)$ and ${ }^{13} \mathrm{C}$ NMR $\left(100 \mathrm{MHz}, \mathrm{CDCl}_{3}\right)$ data, see Table 1; HR-ESI-MS: $\mathrm{m} / \mathrm{z} 452.2794[\mathrm{M}+\mathrm{H}]^{+}$(calcd. for $\left.\mathrm{C}_{28} \mathrm{H}_{38} \mathrm{NO}_{4}, 452.2795\right)$.

Talaketides A (7): $\mathrm{C}_{13} \mathrm{H}_{20} \mathrm{O}_{5}$; yellow oil; $[\alpha]_{\mathrm{D}}^{25}-14.09^{\circ}(c$ 0.26, $\mathrm{MeOH}) ; \mathrm{UV}(\mathrm{MeOH})$ $\lambda_{\max }(\log \varepsilon) 252(2.70) \mathrm{nm} ; \mathrm{ECD}(\mathrm{MeOH}) \lambda_{\max }(\Delta \varepsilon) 211(-1.52), 251(+6.85), 301(-2.68)$ $\mathrm{nm} ;{ }^{1} \mathrm{H}\left(400 \mathrm{MHz}, \mathrm{CDCl}_{3}\right)$ and ${ }^{13} \mathrm{C}$ NMR $\left(100 \mathrm{MHz}, \mathrm{CDCl}_{3}\right)$ data, see Tables 2 and 3; HR-ESI-MS: $m / z 279.1197$ [M+Na] ${ }^{+}$(calcd. for $\mathrm{C}_{13} \mathrm{H}_{20} \mathrm{O}_{5} \mathrm{Na}$, 279.1203).

Talaketides B (8): $\mathrm{C}_{9} \mathrm{H}_{12} \mathrm{O}_{5}$; yellow oil; $[\alpha]_{\mathrm{D}}^{25}+3.69^{\circ}$ ( $\left.0.24, \mathrm{MeOH}\right) ; \mathrm{UV}(\mathrm{MeOH})$ $\lambda_{\max }(\log \varepsilon) 240(3.28), 295(2.53) \mathrm{nm} ; \mathrm{ECD}(\mathrm{MeOH}) \lambda_{\max }(\Delta \varepsilon) 208$ (-2.95), $241(-5.73), 294$ $(+2.65) \mathrm{nm} ;{ }^{1} \mathrm{H}\left(400 \mathrm{MHz}, \mathrm{CDCl}_{3}\right)$ and ${ }^{13} \mathrm{C} \mathrm{NMR}\left(100 \mathrm{MHz}, \mathrm{CDCl}_{3}\right)$ data, see Tables 2 and 3; HR-ESI-MS: $m / z$ 223.0574 [M+Na] ${ }^{+}$(calcd. for $\mathrm{C}_{9} \mathrm{H}_{12} \mathrm{O}_{5} \mathrm{Na}$, 233.0577).

Talaketides C (9): $\mathrm{C}_{15} \mathrm{H}_{24} \mathrm{O}_{5}$; yellow oil; $[\alpha]_{\mathrm{D}}^{25}+2.96^{\circ}(c 1.12, \mathrm{MeOH}) ; \mathrm{UV}(\mathrm{MeOH})$ $\lambda_{\max }(\log \varepsilon) 261(2.94) \mathrm{nm} ; \mathrm{ECD}(\mathrm{MeOH}) \lambda_{\max }(\Delta \varepsilon) 205(+0.36), 243(-3.35), 262(+0.97), 307$ $(+0.60) \mathrm{nm} ;{ }^{1} \mathrm{H}\left(400 \mathrm{MHz}, \mathrm{CDCl}_{3}\right)$ and ${ }^{13} \mathrm{C} \mathrm{NMR}\left(100 \mathrm{MHz}, \mathrm{CDCl}_{3}\right)$ data, see Tables 2 and 3; HR-ESI-MS: $m / z$ 307.1517 [M+Na] ${ }^{+}$(calcd. for $\mathrm{C}_{15} \mathrm{H}_{24} \mathrm{O}_{5} \mathrm{Na}, 307.1516$ ).

Talaketides D (10): $\mathrm{C}_{9} \mathrm{H}_{14} \mathrm{O}_{4}$; yellow oil; $[\alpha]_{\mathrm{D}}^{25}+16.04^{\circ}(c 0.24, \mathrm{MeOH}) ; \mathrm{UV}(\mathrm{MeOH})$ $\lambda_{\max }(\log \varepsilon) 251(2.84) \mathrm{nm} ; \mathrm{ECD}(\mathrm{MeOH}) \lambda_{\max }(\Delta \varepsilon) 205(+0.52), 252(-2.08), 296(+1.02)$ $\mathrm{nm} ;{ }^{1} \mathrm{H}\left(400 \mathrm{MHz}, \mathrm{CDCl}_{3}\right)$ and ${ }^{13} \mathrm{C}$ NMR $\left(100 \mathrm{MHz}, \mathrm{CDCl}_{3}\right)$ data, see Tables 2 and 3; HR-ESI-MS: $m / z 209.0783$ [M+Na] ${ }^{+}$(calcd. for $\mathrm{C}_{9} \mathrm{H}_{14} \mathrm{O}_{4} \mathrm{Na}, 209.0784$ ).

Talaketides E (11): $\mathrm{C}_{9} \mathrm{H}_{14} \mathrm{O}_{4}$; yellow oil; $[\alpha]_{\mathrm{D}}^{25}-11.35^{\circ}(c \mathrm{c} 25, \mathrm{MeOH}) ; \mathrm{UV}(\mathrm{MeOH})$ $\lambda_{\max }(\log \varepsilon) 252(2.81) \mathrm{nm} ; \mathrm{ECD}(\mathrm{MeOH}) \lambda_{\max }(\Delta \varepsilon) 216(-0.23), 249(+0.60), 323(-0.26)$ $\mathrm{nm} ;{ }^{1} \mathrm{H}\left(400 \mathrm{MHz}, \mathrm{CDCl}_{3}\right)$ and ${ }^{13} \mathrm{C}$ NMR $\left(100 \mathrm{MHz}, \mathrm{CDCl}_{3}\right)$ data, see Tables 2 and 3; HR-ESI-MS: $m / z 209.0784$ [M+Na] ${ }^{+}$(calcd. for $\mathrm{C}_{23} \mathrm{H}_{33} \mathrm{O}_{6}, 209.0784$ ).

Talaketides $\mathrm{F}(12)$ : $\mathrm{C}_{19} \mathrm{H}_{25} \mathrm{ClO}_{5}$; yellow oil; $[\alpha]_{\mathrm{D}}^{25}+49.14^{\circ}(c 0.19, \mathrm{MeOH}) ; \mathrm{UV}(\mathrm{MeOH})$ $\lambda_{\max }(\log \varepsilon) 252(2.91) \mathrm{nm} ; \mathrm{ECD}(\mathrm{MeOH}) \lambda_{\max }(\Delta \varepsilon) 201(+1.09), 256(-1.52), 294(+1.24)$ $\mathrm{nm} ;{ }^{1} \mathrm{H}\left(400 \mathrm{MHz}, \mathrm{CDCl}_{3}\right)$ and ${ }^{13} \mathrm{C}$ NMR $\left(100 \mathrm{MHz}, \mathrm{CDCl}_{3}\right)$ data, see Tables 2 and 3; HR-ESI-MS: $m / z 369.1468[\mathrm{M}+\mathrm{H}]^{+}$(calcd. for $\mathrm{C}_{19} \mathrm{H}_{26} \mathrm{ClO}_{5}, 369.1468$ ).

\subsection{Molecular Networking}

The crude extract of CY-3 was analyzed by LC-MS/MS (LTQ Velos Pro-Orbitrap, Waltham, MA, USA) and a $\mathrm{C}_{18}$ column (Thermo Fisher Scientific-packed Hypersil GOLD, $1.9 \mu \mathrm{m}, 2.1 \times 100 \mathrm{~mm}$ ). Samples were dissolved in $\mathrm{MeCN}$ at $1 \mathrm{mg} / \mathrm{mL}$. A $10 \mu \mathrm{L}$ of sample was injected and eluted with a gradient of $\mathrm{H}_{2} \mathrm{O}$ containing $0.1 \% \mathrm{HCOOH}$ and MeCN containing $0.1 \% \mathrm{HCOOH}$ with a gradient method as follows: $10 \% \mathrm{MeCN} / \mathrm{H}_{2} \mathrm{O}$ for $1 \mathrm{~min}, 10 \% \mathrm{MeCN} / \mathrm{H}_{2} \mathrm{O}$ to $60 \%$ in $9 \mathrm{~min}, 60 \% \mathrm{MeCN} / \mathrm{H}_{2} \mathrm{O}$ to $90 \%$ in $3 \mathrm{~min}$, held at $90 \% \mathrm{MeCN} / \mathrm{H}_{2} \mathrm{O}$ for $3 \mathrm{~min}$, then $90 \% \mathrm{MeCN} / \mathrm{H}_{2} \mathrm{O}$ to $10 \% \mathrm{MeCN} / \mathrm{H}_{2} \mathrm{O}$ in $0.2 \mathrm{~min}$, and finally held at $10 \% \mathrm{MeCN} / \mathrm{H}_{2} \mathrm{O}$ for $3.8 \mathrm{~min}$ with the flow rate of $0.3 \mathrm{~mL} / \mathrm{min}$. Mass spectra were recorded in positive ESI mode $(\mathrm{m} / \mathrm{z} 200-2000)$ and with an automated fully dependent MS/MS scan enabled. The molecular networking were made as described previously $[27,28]$.

\subsection{ECD and ${ }^{13} C$ NMR Calculations}

ECD calculations and 13C NMR calculations were performed by the Gaussian 09 program and Spartan'14. The conformation with a Boltzmann population greater than $5 \%$ was selected for optimization and calculation in methanol at B3LYP / 6-31+G $(d, p)$. The ECD spectra were generated by the program SpecDis 1.6 (University of Würzburg, Würzburg, Germany) and drawn by OriginPro 8.0 (OriginLab, Ltd., Northampton, MA, USA) from dipole-length rotational strengths by applying Gaussian band shapes with sigma $=0.30 \mathrm{eV}[29,30]$. 


\subsection{Bioassay}

Compounds 1-12 were evaluated for $\alpha$-glucosidase inhibitory activity, as described previously [31]. Three parallel concentrations of 1-deoxynojirimycin were taken as positive controls. DMSO was used as blank controls.

\subsection{Molecular Docking}

Because the crystal structure of glucosidase from Saccharomyces cerevisiae cannot be obtained, the $\alpha$-glucosidase homology model (PDB:3AXH) provided by SWISSMODEL Repository was used, and the model quality was evaluated [29]. The $\alpha$-glucosidase homology model (PDB:3AXH) with compounds 1-5 was performed on Autodock, as described previously [31-34].

\section{Conclusions}

In summary, two new sambutoxin derivatives (1-2) and six new highly oxygenated polyketides derivatives (7-12), together with four known compounds (3-6), were obtained using guidance through molecular networking from semimangrove endophytic fungus Talaromyces sp. CY-3. The structures of new isolates were elucidated by $1 \mathrm{D}$ and 2D NMR, HR-ESI-MS, ECD spectra, ${ }^{13}$ C NMR calculation, and DP4+ analysis, as well as chemical hydrolysis. The absolute configuration of sambutoxin derivatives (1-2) was determined through ${ }^{13} \mathrm{C}$ NMR calculation and DP4+ analysis for the first time. In bioassays, compounds $\mathbf{1}-\mathbf{5}$ displayed better $\alpha$-glucosidase inhibitory activity with $\mathrm{IC}_{50}$ values in the range of $12.6 \pm 0.9$ to $57.3 \pm 1.3 \mu \mathrm{M}$ compared to the positive control 1-deoxynojirimycin $\left(\mathrm{IC}_{50}=80.8 \pm 0.3 \mu \mathrm{M}\right)$.

Supplementary Materials: The following are available online at https:/ / www.mdpi.com/article/ $10.3390 / \mathrm{md} 19090492 / \mathrm{s} 1$, Figure S1 LC-MS/MS of CY-3. Figure S2 ${ }^{1} \mathrm{H}$ NMR of 1 . Figure S3 ${ }^{13} \mathrm{C}$ NMR of $\mathbf{1}$. Figure S4 DEPT 135 of $\mathbf{1}$. Figure S5 HSQC spectrum of $\mathbf{1}$. Figure S6 HMBC spectrum of 1 . Figure S7 COSY spectrum of 1 . Figure S8 NOESY spectrum of 1 . Figure S9 HR-ESI-MS spectrum of 1. Figure S10 UV spectrum of $\mathbf{1}$. Figure $\mathrm{S} 11{ }^{1} \mathrm{H}$ NMR of 2. Figure $\mathrm{S} 12{ }^{13} \mathrm{C}$ NMR of 2. Figure S13 DEPT 135 of 2. Figure S14 HSQC spectrum of 2. Figure S15 HMBC spectrum of 2. Figure S16 COSY spectrum of 2. Figure S17 NOESY spectrum of 2. Figure S18 HR-ESI-MS spectrum of 2. Figure S19 UV spectrum of 2. Figure S20 ${ }^{1} \mathrm{H}$ NMR of 7. Figure $\mathrm{S} 21{ }^{13} \mathrm{C}$ NMR of 7 . Figure S22 HSQC spectrum of 7. Figure S23 HMBC spectrum of 7. Figure S24 COSY spectrum of 7. Figure S25 NOESY spectrum of 7. Figure S26 HR-ESI-MS spectrum of 7. Figure S27 UV spectrum of 7. Figure S28 ${ }^{1} \mathrm{H}$ NMR of 8 . Figure S29 ${ }^{13} \mathrm{C}$ NMR of 8. Figure S30 HSQC spectrum of 8. Figure S31 HMBC spectrum of 8 . Figure S32 COSY spectrum of 8. Figure S33 NOESY spectrum of 8. Figure S34 HR-ESI-MS spectrum of 8. Figure S35 UV spectrum of 8. Figure S36 ${ }^{1} \mathrm{H}$ NMR of 9. Figure S37 ${ }^{13} \mathrm{C}$ NMR of 9. Figure S38 HSQC spectrum of 9. Figure S39 HMBC spectrum of 9. Figure S40 COSY spectrum of 9. Figure S41 NOESY spectrum of 9. Figure S42 HR-ESI-MS spectrum of 9. Figure S43 UV spectrum of 9. Figure $S 44{ }^{1} \mathrm{H}$ NMR of 10. Figure $S 45{ }^{13} \mathrm{C}$ NMR of $\mathbf{1 0}$. Figure S46 HSQC spectrum of 10. Figure S47 HMBC spectrum of 10. Figure S48 COSY spectrum of 10. Figure S49 NOESY spectrum of 10. Figure S50 HR-ESI-MS spectrum of 10. Figure S51 UV spectrum of 10. Figure $552{ }^{1} \mathrm{H}$ NMR of 11. Figure $S 53{ }^{13} \mathrm{C}$ NMR of 11. Figure S54 HSQC spectrum of 11. Figure S55 HMBC spectrum of 11. Figure S56 COSY spectrum of 11. Figure S57 NOESY spectrum of 11. Figure S58 HR-ESI-MS spectrum of 11. Figure S59 UV of 11. Figure S60 ${ }^{1} \mathrm{H}$ NMR of 12. Figure $S 61{ }^{13} \mathrm{C} N M R$ of 12. Figure S62 HSQC spectrum of 12. Figure $S 63 \mathrm{HMBC}$ spectrum of 12. Figure S64 COSY spectrum of 12. Figure S65 NOESY spectrum of 12. Figure S66 HR-ESI-MS spectrum of 12. Figure S67 UV spectrum of 12. Figure S68 Comparison of the experimental ${ }^{13} \mathrm{C}$ NMR data of the 2,4,6-trimethyloct-2-ene side chain for compound 1 and the calculated chemical shifts for four 2,4,6-trimethyloct-2-ene side-chain diastereomers (14R,16S-1, 14R,16R-1 14S,16R-1, and 14S, 16S-1). Figure S69 DP4+ analysis of 1 . Figure S70 Comparison of the experimental ${ }^{13} \mathrm{C}$ NMR data of the 2,4,6-trimethyloct-2-ene side chain for compound 2 and the calculated chemical shifts for four 2,4,6-trimethyloct-2-ene side-chain diastereomers $(14 R, 16 S-2,14 R, 16 R-2$ 14S,16R-2, and 14S, 16S-2). Figure S71 DP4+ analysis of 2. Figure S72 Hydrolysis of 7 and 9 compared with the standard through HPLC chiral column. 
Author Contributions: W.Y. performed the large-scale fermentation and isolated all compounds. W.Y. and Y.C. carried out the structure elucidation and edited the manuscript. J.W. carried out the biological assays. Q.T., Y.Y., Y.Z. and L.G. participated in the experiments. B.W. and Z.S. designed and supervised this research. All authors have read and agreed to the published version of the manuscript.

Funding: This research was funded by the National Natural Science Foundation of China (U20A2001, 21877133), the Key-Area Research and Development Program of Guangdong Province (2020B1111030005), the National Key R\&D Program of China (2019YFC0312501), the Key Project of Natural Science Foundation of Guangdong Province (2016A030311026) and the Fundamental Research Funds for the Central Universities (No. 20ykjc04) for generous support.

Institutional Review Board Statement: Not applicable.

Data Availability Statement: Data are contained within the article and Supplementary Material.

Acknowledgments: We acknowledge the IARC, SYSU for support towards LC-MS equipment. We also thank SCSIO for the generous support towards ECD equipment.

Conflicts of Interest: The authors declare no conflict of interest.

\section{References}

1. Dhameja, M.; Gupta, P. Synthetic heterocyclic candidates as promising $\alpha$-glucosidase inhibitors: An overview. Eur. J. Med. Chem. 2019, 176, 343-377. [CrossRef] [PubMed]

2. Rajalakshmi, R.; Lalitha, P.; Sharma, S.C.; Rajiv, A.; Chithambharan, A.; Ponnusamy, A. In Silico studies: Physicochemical properties, drug score, toxicity predictions and molecular docking of organosulphur compounds against Diabetes mellitus. J. Mol. Recognit. 2021, e2925. [CrossRef]

3. Carroll, A.R.; Coop, B.R.; Davis, R.A.; Keyzers, R.A.; Prinsep, M.R. Marine natural products. Nat. Prod. Rep. 2021, $38,362-413$. [CrossRef] [PubMed]

4. $\quad$ Blunt, J.W.; Carroll, A.R.; Coop, B.R.; Davis, R.A.; Keyzers, R.A.; Prinsep, M.R. Marine natural products. Nat. Prod. Rep. 2018, 16, 319-349. [CrossRef] [PubMed]

5. Liu, Y.Y.; Yang, Q.; Xia, G.P.; Huang, H.B.; Li, H.X.; Ma, L.; Lu, Y.J.; He, L.; Xia, X.K.; She, Z.G. Polyketides with $\alpha$-glucosidase inhibitory activity from a mangrove endophytic fungus, Penicillium sp. HN29-3B1. J. Nat. Prod. 2015, 78, 1816-1822. [CrossRef] [PubMed]

6. Chen, S.H.; Chen, D.N.; Cai, R.L.; Cui, H.; Long, Y.H.; Lu, Y.J.; Li, C.Y.; She, Z.G. Cytotoxic and antibacterial preussomerins from the mangrove endophytic fungus Lasiodiplodia theobromae ZJ-HQ1. J. Nat. Prod. 2016, 79, 2397-2402. [CrossRef]

7. $\quad$ Liang, Z.Y.; Shen, N.X.; Zheng, Y.Y.; Wu, J.T.; Miao, L.; Fu, X.M.; Chen, M.; Wang, C.Y. Two new unsaturated fatty acids from the mangrove rhizosphere soil-derived fungus Penicillium javanicum HK1-22. Bioorg. Chem. 2019, 93, 103331. [CrossRef]

8. An, C.Y.; Li, X.M.; Li, C.S.; Wang, M.H.; Xu, G.M.; Wang, B.G. Aniquinazolines A-D, four new quinazolinone alkaloids from marine-derived endophytic fungus Aspergillus nidulans. Mar. Drugs 2013, 11, 2682-2694. [CrossRef]

9. Chen, Y.; Liu, Z.M.; Huang, Y.; Liu, L.; He, J.G.; Wang, L.; Yuan, J.; She, Z.G. Ascomylactams A-C, cytotoxic 12- or 13-memberedring macrocyclic alkaloids isolated from the mangrove endophytic fungus Didymella sp. CYSK-4, and structure eevisions of phomapyrrolidones A and C. J. Nat. Prod. 2019, 82, 1752-1758. [CrossRef]

10. Peng, J.X.; Lin, T.; Wang, W.; Xin, Z.H.; Zhu, T.J.; Gu, Q.Q.; Li, D.H. Antiviral alkaloids produced by the mangrove-derived fungus Cladosporium sp. PJX-41. J. Nat. Prod. 2013, 76, 1133-1140. [CrossRef]

11. Zou, G.; Tan, Q.; Chen, Y.; Yang, W.C.; Zang, Z.M.; Jiang, H.M.; Chen, S.Y.; Wang, B.; She, Z.G. Furobenzotropolones A, B and 3-hydroxyepicoccone B with antioxidative activity from mangrove endophytic fungus Epicoccum nigrum MLY-3. Mar. Drugs 2021, 19, 395. [CrossRef]

12. Chen, Y.; Yang, W.C.; Zou, G.; Yan, Z.Y.; Qiu, P.; Long, Y.H.; She, Z.G. Metabolites with anti-inflammatory and alpha-glucosidase inhibitory activities from the mangrove endophytic fungus Phoma sp. SYSU-SK-7. Tetrahedron Lett. 2020, 61, 152578. [CrossRef]

13. Cai, R.L.; Wu, Y.N.; Chen, S.H.; Cui, H.; Liu, Z.M.; Li, C.Y.; She, Z.G. Peniisocoumarins A-J: Isocoumarins from Penicillium commune QQF-3, an endophytic fungus of the mangrove plant Kandelia candel. J. Nat. Prod. 2018, 81, 1376-1383. [CrossRef]

14. Wu, Y.N.; Chen, Y.; Huang, X.S.; Pan, Y.H.; Liu, Z.M.; Yan, T.; Cao, W.H.; She, Z.G. $\alpha$-Glucosidase inhibitors: Diphenyl ethers and phenolic bisabolane sesquiterpenoids from the mangrove endophytic fungus Aspergillus flavus QQSG-3. Mar. Drugs 2018, 16, 307. [CrossRef]

15. Allard, P.M.; Péresse, T.; Bisson, J.; Gindro, K.; Marcourt, L.; Pham, V.C.; Roussi, F.; Litaudon, M.; Wolfender, J.L. Integration of molecular networking and in-silico MS/MS fragmentation for natural products dereplication. Anal. Chem. 2016, 88, 3317-3323. [CrossRef]

16. Nie, Y.Y.; Yang, W.C.; Liu, Y.Y.; Yang, J.M.; Lei, X.L.; Gerwick, W.H.; Zhang, Y. Acetylcholinesterase inhibitors and antioxidants mining from marine fungi: Bioassays, bioactivity coupled LC-MS/MS analyses and molecular networking. Mar. Life Sci. Technol. 2020, 2, 386-397. [CrossRef] 
17. Gu, B.; Wu, Y.; Tang, J.; Jiao, W.; Li, L.; Sun, F.; Wang, S.; Yang, F.; Lin, H. Azaphilone and isocoumarin derivatives from the sponge-derived fungus Eupenicillium sp. 6A-9. Tetrahedron Lett. 2018, 59, 3345-3348. [CrossRef]

18. Huo, C.; Lu, X.; Zheng, Z.; Li, Y.; Xu, Y.; Zheng, H.; Niu, Y. Azaphilones with protein tyrosine phosphatase inhibitory activity isolated from the fungus Aspergillus deflectus. Phytochemistry 2020, 170, 112224. [CrossRef]

19. Kim, J.C.; Lee, Y.W.; Tamura, H.; Yoshizawa, T. Sambutoxin: A new mycotoxin isolated from Fusarium sambucinum. Tetrahedron Lett. 1995, 36, 1047-1050. [CrossRef]

20. Williams, D.R.; Turske, R.A. Construction of 4-hydroxy-2-pyridinones. Total synthesis of (+)-sambutoxin. Org. Lett. 2000, 2, 3217-3220. [CrossRef] [PubMed]

21. Chunyu, W.X.; Zhao, J.Y.; Ding, Z.G.; Han, X.L.; Wang, Y.X.; Ding, J.H.; Wang, F.; Li, M.G.; Wen, M.L. A new cyclohexenone from the tin mine tailingsderived fungus Aspergillus flavus YIM DT 10012. Nat. Prod. Res. 2019, 33, 113-116. [CrossRef]

22. Matsumoto, M.; Minato, H. Structure of ilicicolin H, an antifungal antibiotic. Tetrahedron Lett. 1976, 42, 3827-3830. [CrossRef]

23. Sinder, B.B.; Lu, Q. Total synthesis of ( \pm )-leporin A. J. Org. Chem. 1996, 61, 2839-2844. [CrossRef]

24. Zhang, C.; Jin, L.; Mondie, B.; Mitchell, S.S.; Castelhano, A.L.; Cai, W.; Bergenhem, N. Leporin B: A novel hexokinase II gene inducing agent from an unidentified fungus. Bioorg. Med. Chem. Lett. 2003, 13, 1433-1435. [CrossRef]

25. Zhang, Z.; Jamieson, C.S.; Zhao, Y.; Li, D.; Ohashi, M.; Houk, K.N.; Tang, Y. Enzyme-catalyzed inverse-electron demand Diels-Alder reaction in the biosynthesis of antifungal ilicicolin H. J. Am. Chem. Soc. 2019, 141, 5659-5663. [CrossRef]

26. Millot, M.; Dieu, A.; Tomosi, S. Dibenzofurans and derivatives from lichens and ascomycetes. Nat. Prod. Rep. 2016, 33, 801-811. [CrossRef] [PubMed]

27. Wang, M.; Carver, J.J.; Phelan, V.V.; Sanchez, L.M.; Garg, N.; Peng, Y.; Nguyen, D.D.; Watrous, J.; Kapono, C.A.; Luzzatto-Knaan, T.; et al. Sharing and community curation of mass spectrometry data with Global Natural Products Social Molecular Networking. Nat. Biotechnol. 2016, 34, 828-837. [CrossRef] [PubMed]

28. Li, Y.; Yu, H.B.; Zhang, Y.; Leao, T.; Glukhov, E.; Pierce, M.L.; Zhang, C.; Kim, H.; Mao, H.H.; Fang, F.; et al. Pagoamide A, a cyclic depsipeptide isolated from a cultured marine chlorophyte, Derbesia sp., using MS/MS-based molecular networking. J. Nat. Prod. 2020, 83, 617-625. [CrossRef] [PubMed]

29. Cui, H.; Liu, Y.N.; Li, J.; Huang, X.S.; Yan, T.; Cao, W.H.; Liu, H.J.; Long, Y.H.; She, Z.G. Diaporindenes A-D: Four unusual 2,3-dihydro-1H-indene analogues with anti-inflammatory activities from the mangrove endophytic fungus Diaporthe sp. SYSU. J. Org. Chem. 2018, 83, 11804-11813. [CrossRef]

30. Frisch, M.J.; Trucks, G.W.; Schlegel, H.B.; Scuseria, G.E.; Robb, M.A.; Cheeseman, J.R.; Scalmani, G.; Barone, V.; Mennucci, B.; Petersson, G.A.; et al. Gaussian 09; Gaussian, Inc.: Wallingford, UK, 2016.

31. Ye, G.J.; Lan, T.; Huang, Z.X.; Cheng, X.N.; Cai, C.Y.; Ding, S.M.; Xie, M.L.; Wang, B. Design and synthesis of novel xanthonetriazole derivatives aspotential antidiabetic agents: $\alpha$-glucosidase inhibition and glucoseuptake promotion. Eur. J. Med. Chem. 2019, 177, 362-373. [CrossRef]

32. Chen, T.; Huang, Y.; Hong, J.; Wei, X.; Zeng, F.; Li, J.; Ye, G.; Yuan, J.; Long, Y. Preparation, COX-2 inhibition and anticancer activity of sclerotiorin derivatives. Mar. Drugs 2021, 19, 12. [CrossRef] [PubMed]

33. DeLano, W.L. The PyMOL Molecular Graphics System. 2002. Available online: http:/ / www.pymol.org (accessed on 30 August 2020).

34. Wallace, A.C.; Laskowski, R.A.; Thornton, J.M. LIGPLOT: A program to generate schematic diagrams of protein-ligand interactions. Protein Eng. 1995, 8, 127-134. [CrossRef] [PubMed] 